\title{
GENETIC DIVERSITY AND GENE FLOW IN YELLOWSTONE BASIN PRONGHORN (ANTILOCAPRA AMERICANA)
}

\author{
K. K. BARNOW-MEYeR AND J. A. BYERS $\downarrow$ DEPARTMENT OF BIOlOGICAL SCIENCES \\ UNIVERSITY OF IDAHO $\downarrow$ BOISE
}

\begin{abstract}
$\downarrow \quad$ Abstract
Yellowstone National Park's northern range is home to a geographically isolated population of pronghorn (Antilocapra americana) greatly reduced from historic levels of abundance. The genetic consequences of demographic declines in this population over the past 150 years are unknown, and the rates of genetic exchange among this and other populations in the Yellowstone basin are also unknown. We used 18 nuclear DNA microsatellite loci and noninvasively collected fecal samples from 73 individuals to quantify basic population genetic parameters and gene flow within and among the Yellowstone pronghorn population, a new population in the Paradise Valley, and a large population near Livingston, MT. Evidence for a genetic bottleneck in Yellowstone was strong based on several tests of heterozygote excess (Wilcoxon tests $\mathrm{P} \leq 0.033$ ) and the relative ratio of allele richness to allele size range $(\mathrm{M}=$ 0.283 ). However, mean population heterozygosity was high $(\mathrm{HO}=0.665)$, and no indications of inbreeding were detected. Gene flow from elsewhere in the Yellowstone basin to Yellowstone National Park is extremely low. However, emigration from Yellowstone to the Paradise Valley population is high $(26.7 \%)$, reinforcing conclusions based on behavioral data that this new population was founded by Yellowstone individuals. Despite years of population decline and genetic isolation, Yellowstone pronghorn appear to retain substantial genetic diversity.
\end{abstract}

\section{$\downarrow$ INTRODUCTION}

Yellowstone National Park's northern range is home to a geographically isolated population of pronghorn (Antilocapra americana) at severe risk of extirpation (National Research Council 2002). Like many pronghorn populations across western North America, Yellowstone's pronghorn herd has experienced a dramatic decline in abundance over the past two centuries (Keating 2002). Prior to the establishment of Yellowstone as a national park in 1872, thousands of pronghorn were killed each year within the present-day park boundary until scarcity and protection by the U.S. Army in 1886 halted the decline (Keating 2002). With the exception of a single population irruption in 1990 (White et al. 2007a), estimates of the Yellowstone pronghorn population have remained at or below 500 individuals since 1947 (Keating 2002). This population previously migrated over $80 \mathrm{~km}$ from summer ranges within present-day Yellowstone National Park (YNP) to an expansive winter range near Livingston, MT to the north. Beginning in 1902, human settlement and fencing in the Paradise Valley effectively ended their migration north of the park (Skinner 1922) and reduced the population's winter range to a fraction of its former size. These changes also likely severed meaningful connectivity and genetic exchange with neighboring pronghorn populations (Scott and Geisser 1996). Today, the Yellowstone pronghorn population numbers approximately 300 individuals and persists on a heavily-browsed winter range of approximately $30 \mathrm{~km} 2$ (White et al. 2007b, Boccadori et al. 2008). 
The genetic consequences of this dramatic demographic and range constriction are unknown. The apparent lack of connectivity with neighboring populations could lead to reproductive depression due to inbreeding, dramatically impacting the long-term viability of this population (Goodman 1996). Lee et al. (1994) found that Yellowstone pronghorn retain relatively high levels of variation based on allozyme data ( $\mathrm{n}=11$ individuals). The authors suggested that Yellowstone pronghorn may possess genetic diversity once widespread in historic pronghorn populations but now lost elsewhere except through past translocations of individuals from Yellowstone (Scott 2004). A more complete assessment of the extant genetic diversity of this population would dramatically improve future research and conservation planning for this and derived populations.

Migration between this and formerly connected populations within the Yellowstone River basin would have important implications for the maintenance and spread of genetic diversity potentially present in the YNP pronghorn population. By 2002, a small non-introduced herd of reproducing pronghorn was established approximately $30 \mathrm{~km}$ north of the park in Paradise Valley and increased to more than 70 animals in 2008. These animals mark the first significant return of pronghorn to the southern Paradise Valley since the early 20 th century. The provenance of these individuals is unknown, but at least two marked, female pronghorn dispersed from the Yellowstone population to contribute to the initial establishment of this southern Paradise Valley herd (NPS, unpublished data). Genetic data supporting this, and data reflecting movement of individuals between Yellowstone and pronghorn in the Livingston, MT area north of Paradise Valley are lacking at this time.

Within the Yellowstone River basin, understanding patterns of gene flow may help explain historic range abandonment within YNP (Keating 2002), prevent future habitat restrictions due to NPS and private infrastructure development (Scott 1992, White et al. 2007b), and aid reintroduction efforts should a catastrophic decrease in abundance occur. To meet these data deficiencies and conservation goals, we comprehensively characterized the genetics of the Yellowstone pronghorn population and the recentlyestablished population in Paradise Valley. We documented overall genetic diversity and heterozygosity of females and assessed evidence for a genetic bottleneck brought about by historic changes in population abundance. In addition, we used Bayesian analytical methods to estimate recent rates of migration between pronghorn groups in Yellowstone National
Park, central Paradise Valley, and the lower Yellowstone Basin beyond Livingston, Montana.

\section{METHODS}

\section{Genetic Data}

Naturally deposited fecal samples were collected between early June and early August 2006 from undisturbed pronghorn on the northern range of Yellowstone National Park and the Point of Rocks area of Paradise Valley ca. $30 \mathrm{~km}$ north of Gardiner, MT (Figure 1). In July 2007, additional fecal samples were collected from pronghorn within the foothills between the Yellowstone and Boulder Rivers ca. $30 \mathrm{~km}$ east of Livingston, MT. Pronghorn groups were located from the ground. Visual observation of defecation events was used to assign separate identities to each sample. Samples were placed in sanitized plastic bags within one hour of deposition, labeled with collection data (date, time, Universal Transverse Mercator coordinates, individual sex, and approximate age (juvenile versus adult)), and transferred to a freezer within 8 hours of collection. Only adult female samples were used for analyses.

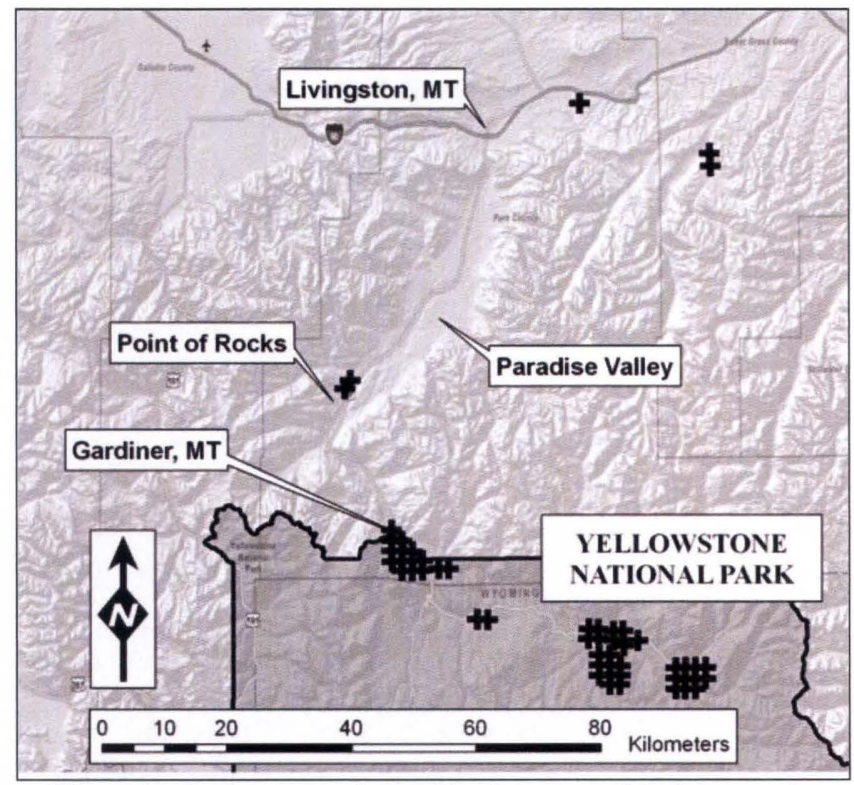

Figure 1. Study area and sampling locations (black crosses) for pronghorn in the upper Yellowstone River basin, Montana/Wyoming, USA. Pronghorn within Yellowstone National Park constitute a single, partially-migratory population (White et al. 2007b).

DNA was extracted from fecal samples in a room dedicated to low quantity DNA sources using the QIAamp DNA Stool Mini Kit (QIAGEN Inc., Valencia CA) with modification: target cells on the outer surface 
of the pellet were washed free for analysis using Buffer ASL rather than extracted from the entire homogenized pellet (Wehausen et al. 2004). Analyses were conducted using 18 microsatellite loci: Aam1-Aam8 (Carling et al. 2003), ADCYC (Lou 1998), PrM6506 (Stephen et al. 2005a), A103, A7, C10, D115, D116, A106, A11, A118, A12, and C102 (in manuscript). DNA fragments were amplified using polymerase chain reaction (PCR). PCR products were analyzed using an ABI Prism 3130xl capillary system (Applied Biosystems, Foster City CA) and GENEMAPPER 3.5 (ABI). Negative controls were included during the extraction and PCR to monitor for contamination. Consensus genotypes were determined based on 3-6 PCR replicates per sample using visual inspection. Genotypes were accepted if alleles were observed 3 times in the case of homozygotes and at least 2 times each in the case of heterozygotes. Consensus genotypes were then verified using the consensus genotype function of GIMLET (Valiere 2002). Probability of identity and probability of identity siblings (Waits et al. 2001) was assessed using GIMLET, and duplicate samples for the same individual were removed as appropriate. Error rates for allelic dropout and false alleles were calculated in GIMLET.

\section{Standard Population Parameters}

We calculated the mean population and individual multilocus heterozygosity, allele frequencies, the mean number of alleles per locus, allelic richness, departure from Hardy-Weinberg equilibrium, and linkage disequilibria between loci using ARLEQUIN 3.11 (Schneider et al. 2000).

\section{Yellowstone Population Bottleneck}

Heterozygote excess relative to that expected from the observed allele number at mutation-drift equilibrium (a measure of recent bottleneck events) under infinite allele (Kimura and Crow 1964), twophase (Di Rienzo et al. 1994), and stepwise (Ohta and Kimura 1973) mutation models was assessed using BOTTLENECK (Cornuet and Luikart 1997). We further assessed evidence for an historic decline in population size using the mean ratio of the number of alleles $(\mathrm{k})$ to the adjusted range in allele size (r) across loci $(\mathrm{M}=\mathrm{k} / \mathrm{r}$; Garza and Williamson 2001). During a reduction in population size, the rate of loss of rare alleles will exceed the rate of contraction in the range of allele sizes. Thus, $\mathrm{M}$ is expected to be smaller in recently reduced populations than in populations at equilibrium (Garza and Williamson 2001).

\section{Gene Flow}

We estimated rates of gene flow between areas of the Yellowstone River basin using the program BayesAss+, Version 1.3 (Wilson and Rannala 2003). BayesAss+ uses Markov Chain Monte Carlo (MCMC) simulation techniques to derive migration rates and does not assume groups are in Hardy-Weinberg or migration-drift equilibrium or that migration rates are constant. The program was allowed to run $3 \times 106$ iterations with a thinning interval of $2 \times 103$ and a burnin period of 106 iterations. Delta values for the allele frequency, migration rate, and inbreeding value were set at 0.15 to ensure that proposed changes in the Markov chain were between $40 \%$ and $60 \%$ (Wilson and Rannala 2003). Two subsequent runs were conducted using differing values of the random seed to ensure stability in migration rate estimates. To evaluate the strength of the information in each dataset, $95 \%$ confidence intervals were determined for estimated rates and compared to simulation results in which no information was contained in the dataset.

\section{$\downarrow \quad$ RESUlTS}

\section{Sample Quality}

Overall extraction and amplification success of fecal samples was 0.851 . Across replicate runs, the percent of positive PCRs per locus averaged 0.89 and ranged from 0.75 (PMS2) to 0.99 (A106). Allelic dropout across loci averaged 0.1195 (range 0.020 [ADCYC]-0.254 [D116]) and the frequency of false alleles averaged 0.0655 (range 0.0 [A106]-0.216 [PMS7]). The probability of identity was low across loci $(\mathrm{PI}=1.649 \times 10-13$ and $\mathrm{PI}($ sibs $)=4.813 \times 10-5)$ due to high numbers of alleles per locus, indicating a high power to differentiate individuals and identify duplicate samples. After removal of poorly-amplified and duplicate samples from all areas, 73 individuals (47 from Yellowstone National Park, 8 from Paradise Valley, and 18 from Livingston) were retained for analyses.

\section{Population Genetic Diversity}

One locus (D116) of 18 was out of HardyWeinberg equilibrium in the Yellowstone population ( $\mathrm{P}$ $=0.023$; Table 1 ), yet no linkage disequilibria was detected following Bonferroni correction. Observed mean heterozygosity was high $(\mathrm{HO}=0.665)$, with observed per-locus heterozygosity ranging from 


\begin{tabular}{cccccccc}
\hline Locus Name & $\begin{array}{c}\text { Gene } \\
\text { Copies }\end{array}$ & A & $\begin{array}{c}\text { Allelic } \\
\text { Range }\end{array}$ & $\mathbf{H}_{\mathbf{O}}$ & $\mathbf{H}_{\mathbf{E}}$ & P value & $\mathbf{F}_{\text {IS }}$ \\
\hline ADCYC & 47 & 10 & 16 & 0.809 & 0.840 & 0.717 & 0.038 \\
PMS1 & 47 & 4 & 6 & 0.340 & 0.304 & 1.000 & -0.121 \\
PMS10 & 46 & 2 & 2 & 0.522 & 0.502 & 1.000 & -0.041 \\
PMS11 & 45 & 6 & 10 & 0.556 & 0.606 & 0.641 & 0.084 \\
PMS2 & 47 & 4 & 18 & 0.426 & 0.548 & 0.127 & 0.226 \\
PMS7 & 42 & 9 & 32 & 0.833 & 0.853 & 0.100 & 0.023 \\
PMS9 & 45 & 3 & 4 & 0.511 & 0.556 & 0.645 & 0.081 \\
PR6506 & 45 & 5 & 10 & 0.333 & 0.316 & 0.802 & -0.054 \\
A103 & 46 & 10 & 30 & 0.867 & 0.817 & 0.601 & -0.062 \\
A7 & 47 & 7 & 20 & 0.787 & 0.784 & 0.612 & -0.004 \\
C10 & 45 & 8 & 40 & 0.837 & 0.773 & 0.716 & -0.084 \\
D115 & 45 & 11 & 64 & 0.844 & 0.884 & 0.289 & 0.045 \\
D116 & 46 & 5 & 52 & 0.543 & 0.675 & 0.023 & 0.197 \\
A106 & 47 & 10 & 30 & 0.936 & 0.866 & 0.477 & -0.082 \\
A11 & 45 & 11 & 44 & 0.864 & 0.876 & 0.454 & 0.015 \\
A118 & 47 & 6 & 18 & 0.565 & 0.643 & 0.149 & 0.123 \\
A12 & 46 & 10 & 34 & 0.867 & 0.848 & 0.795 & -0.022 \\
C102 & 47 & 2 & 4 & 0.532 & 0.431 & 0.167 & -0.237 \\
\hline Mean & 45.8 & 6.83 & 24.11 & 0.665 & 0.674 & 0.518 & 0.007 \\
\hline
\end{tabular}

Table 1: Summary of basic population genetic values for pronghorn in Yellowstone National Park, Montana/Wyoming, USA. The table shows the number of gene copies sampled, the number of alleles per locus (A), the range in allele size, observed (HO) and expected (HE) heterozygosity, the p-value for a Hardy-Weinberg exact test, and inbreeding coefficient (FIS).

\begin{tabular}{cccccccc}
\hline Locus Name & $\begin{array}{c}\text { Gene } \\
\text { Copies }\end{array}$ & A & $\begin{array}{c}\text { Allelic } \\
\text { Range }\end{array}$ & $\mathbf{H}_{\mathbf{O}}$ & $\mathbf{H}_{\mathbf{E}}$ & P value & $\mathbf{F}_{\text {IS }}$ \\
\hline ADCYC & 12 & 5 & 10 & 0.833 & 0.848 & 0.890 & 0.020 \\
PMS1 & 16 & 2 & 2 & 0.500 & 0.400 & 1 & -0.273 \\
PMS10 & 16 & 2 & 2 & 0.125 & 0.325 & 0.199 & 0.632 \\
PMS11 & 14 & 4 & 8 & 0.857 & 0.648 & 0.773 & -0.358 \\
PMS2 & 16 & 3 & 18 & 0.500 & 0.425 & 1 & -0.191 \\
PMS7 & 12 & 3 & 6 & 0.500 & 0.330 & 1 & -0.154 \\
PMS9 & 16 & 2 & 4 & 0.375 & 0.325 & 1 & -0.167 \\
PRM6506 & 14 & 2 & 2 & 0.571 & 0.527 & 1 & -0.091 \\
A103 & 16 & 6 & 22 & 0.875 & 0.792 & 0.946 & -0.144 \\
A7 & 16 & 5 & 20 & 0.750 & 0.767 & 0.558 & 0.023 \\
C10 & 16 & 3 & 32 & 0.750 & 0.633 & 0.701 & -0.200 \\
D115 & 16 & 6 & 56 & 1.000 & 0.867 & 0.935 & -0.167 \\
D116 & 16 & 3 & 4 & 0.375 & 0.342 & 1 & -0.105 \\
A106 & 16 & 5 & 20 & 0.750 & 0.600 & 1 & -0.273 \\
A11 & 16 & 4 & 32 & 0.875 & 0.642 & 0.682 & -0.400 \\
A118 & 16 & 3 & 12 & 0.375 & 0.608 & 0.168 & 0.400 \\
A12 & 16 & 5 & 26 & 1.000 & 0.792 & 1 & -0.287 \\
C102 & 16 & 2 & 4 & 0.125 & 0.125 & - & 0.000 \\
\hline Mean & 15.3 & 3.6 & 15.56 & 0.619 & 0.555 & 0.815 & -0.102 \\
\hline
\end{tabular}

Table 2: Summary of basic population genetic values for pronghorn located in southern Paradise Valley, Montana, USA. The table shows the number of gene copies sampled, the number of alleles per locus $(\mathrm{A})$, the range in allele size, observed $\left(\mathrm{H}_{\mathrm{O}}\right)$ and expected $\left(\mathrm{H}_{\mathrm{E}}\right)$ heterozygosity, the p-value for a Hardy-Weinberg exact test, and inbreeding coefficient $\left(\mathrm{F}_{\mathrm{IS}}\right)$.

0.333 (PRM6506) to 0.936 (A106). Individual multilocus heterozygosity averaged 0.653 (range $0.333-0.889$ ). Evidence for inbreeding was low (FIS = $0.007)$.
For individuals in the Paradise Valley population, no loci were out of Hardy-Weinberg equilibrium, and no linkage disequilibria was detected following Bonferroni correction (Table 2). Observed mean heterozygosity was high $(\mathrm{HO}=0.619)$, with 
observed per-locus heterozygosity ranging from 0.125 (PMS10 and C102) to 1.000 (D115). Inbreeding in the Paradise Valley population was relatively high (FIS = $0.102)$.

\section{Evidence for Bottlenecks in the Yellowstone Population}

Allelic diversity across loci was high in the Yellowstone population (mean number of alleles $=$ 6.83 ; range 2-11), as were the size ranges of many loci (mean allelic range $=24.11$; range $2-64$ ). Consequently, the mean ratio of allelic richness to the range of allele size across loci was low $(\mathrm{M}=0.283)$. Heterozygote excess based on the number of observed alleles in the population was significant under an infinite allele and two-phase mutation model ( $\mathrm{pg}=0.1$, variance $=12$ for the two-phase mutation model; Wilcoxon test for heterozygote excess $\mathrm{P}=0.000$ and 0.033 , respectively), but not under a stepwise mutation model (Wilcoxon test $\mathrm{P}=0.680$ ). The allele frequency distribution was approximately L-shaped and showed no evidence of a mode shift (Luikart et al. 1997).

\section{Rates of Gene Flow}

Estimated rates of migration into Yellowstone National Park from lower areas of the Yellowstone River basin were essentially zero (Table 3 ). Rates of immigration to Yellowstone National Park did not differ significantly from that observed in simulations from data containing no information $($ mean $=0.0837$, $95 \%$ CI $=0.00125,0.261)$, likely suggesting insufficient sampling of one or more populations (Wilson and Rannala 2003).

\begin{tabular}{|c|c|c|c|}
\hline $\begin{array}{c}\text { To YNP } \\
\text { population from: }\end{array}$ & m & SD & $95 \% \mathrm{CI}$ \\
\hline $\begin{array}{c}\text { YNP } \\
\text { (non-migrants) }\end{array}$ & 0.9848 & 0.0157 & $\begin{array}{c}(0.7079 \\
0.9992)\end{array}$ \\
\hline Paradise Valley & 0.0073 & 0.0111 & $(0,0.0324)$ \\
\hline Livingston & 0.0079 & 0.0097 & $(0,0.0320)$ \\
\hline $\begin{array}{l}\text { To Paradise Valley } \\
\text { population from: }\end{array}$ & m & SD & $95 \%$ CI \\
\hline YNP & 0.2672 & 0.0417 & $\begin{array}{l}(0.1505 \\
0.3204)\end{array}$ \\
\hline $\begin{array}{l}\text { Paradise Valley } \\
\text { (non-migrants) }\end{array}$ & 0.7038 & 0.0358 & $\begin{array}{c}(0.6674 \\
0.7905)\end{array}$ \\
\hline Livingston & 0.0290 & 0.0266 & $(0,0.0889)$ \\
\hline
\end{tabular}

Table 3: Directional gene flow estimates $(\mathrm{m}=$ proportion of migrants) for pronghorn populations in the Yellowstone River basin of Montana and Wyoming, USA based on BayesAss + MCMC simulation.

The total rate of immigration to the Paradise Valley population was 0.296 : 0.267 from Yellowstone
National Park and 0.029 from the Livingston area. The rates of migration estimated from Yellowstone National Park and Livingston to Paradise Valley also did not differ significantly from that observed in simulations from data containing no information.

\section{$\downarrow$ DISCUSSION}

\section{Population Genetics}

Several studies have examined the genetics of Yellowstone pronghorn as part of regional assessments. Lee et al. (1994) identified four mitochondrial haplotypes in Yellowstone pronghorn, one of which $(\mathrm{J})$ was deemed unique to this population. However, subsequent work found the same haplotype in 16 of 389 pronghorn in east-central and north-west Arizona (Reat et al. 1999), possibly derived from translocated Yellowstone stock (Rhodes Jr. et al. 1999, Scott 2004). Lou (1998) conducted a distribution-wide assessment of pronghorn populations using 3 microsatellite loci. For a Wyoming 'population' comprised of individuals from Yellowstone National Park; Park Co., Wyoming; and Banner Co., Nebraska, the mean number of alleles per locus was 10.3 and the observed heterozygosity was 0.614 . More recently, Stephen et al. (2005b) conducted a comparative study of pronghorn populations in Texas, Oregon, Arizona, portions of Mexico, and Yellowstone National Park using preserved tissues from Lee et al. (1994) and 5 microsatellite loci. For the Yellowstone samples, they documented a mean number of alleles per locus of 7 , mean observed heterozygosity of 0.636 , and an inbreeding coefficient (FIS) of 0.018 .

Our results indicate that Yellowstone pronghorn retain substantial genetic diversity, with high mean observed heterozygosity $(\mathrm{HO}=0.665)$ and high mean number of alleles per locus (6.833). Evidence for a significant genetic bottleneck of the population is mixed and dependent on the chosen mutation model. Three mutation models are widely applied to microsatellite markers: the infinite allele model (Kimura and Crow 1964), the two-phase model (Di Rienzo et al. 1994), and the stepwise mutation model (Ohta and Kimura 1973). The two-phase model is considered the most appropriate for microsatellite loci (Ellegren 2000, 2004), followed by the stepwise mutation model (Luikart and Cornuet 1998). Interestingly, significant heterozygote excess (based on allelic diversity per locus) was detected under the assumptions of the two-phase and infinite alleles models, but not the stepwise mutation model. Of the three models, the stepwise mutation model is considered the most conservative and the least likely to 
facilitate detection of a bottleneck event (Luikart and Cornuet 1998). Our estimate of M (0.283, the mean ratio of the number of alleles to the allele size range across loci) is exceptionally low (literature range 0.599 0.926; Garza and Williamson 2001) due to wide allelic ranges at several loci. These results suggest a substantial reduction in allelic diversity from historic levels and provide further evidence for an historic genetic bottleneck of this population. However, the mean number of alleles in Yellowstone pronghorn is high relative to many pronghorn populations (Stephen et al. 2005b), suggesting that their genetic diversity remains relatively high.

\section{Gene Flow in the Yellowstone Basin}

Despite limited genetic sampling of pronghorn in the Livingston area, our results appear to indicate an extremely low rate of gene flow to Yellowstone from formerly-utilized winter range areas beyond Livingston, MT. Substantial agricultural and residential development within the northern Paradise Valley may prevent meaningful genetic exchange between herd units through this area. However, the recent colonization of the southern Paradise Valley, maintained by heavy immigration from Yellowstone National Park, suggests that viable pronghorn habitat in this area may be colonized despite current levels of development. The route taken by pronghorn migrating north from the park involves not only agricultural lands but also a narrow canyon occupied by the Yellowstone River and two roads. Our results are consistent with behavioral observations of marked Yellowstone individuals known to have emigrated from the park to the Point of Rocks area in 2002 (NPS, unpublished data). Interestingly, migration between the park and Paradise Valley appears to be strongly asymmetric, with few individuals migrating from Paradise Valley to Yellowstone National Park. The reasons for this are unclear and warrant further study.

Though pronghorn are known to disperse through the park interior on rare occasions (Scott and Geisser 1996), Paradise Valley represents the most likely conduit for gene flow between Yellowstone and neighboring pronghorn populations. Persistence of the recently-formed Paradise Valley population is likely to improve the long-term viability of the Yellowstone National Park population and greatly reduce the likelihood of permanent local extirpation (Hanski and Gilpin 1997). The National Park Service has developed plans in conjunction with restoration experts to reestablish native vegetation dominated by big sagebrush/bluebunch wheatgrass to winter range areas once tilled for agriculture and now supporting invasive alien species. These efforts may promote the retention of Yellowstone pronghorn within the park boundary during the winter months, reducing emigration rates. Conversely, restoration efforts along the park boundary may increase the frequency with which social groups range north of the park across private lands. Park personnel are working with the U.S. Forest Service, State of Montana, private landowners, and conservation organizations to improve habitat and connectivity between the park and historic winter ranges to the north.

\section{LITERATURE CITED}

Boccadori, S.J., P.J. White, R.A. Garrott, J.J. Borkowski and T.L. Davis. 2008. Yellowstone pronghorn alter resource selection after sagebrush decline. Journal of Mammalogy 89:1031-1040.

Carling, M.D., C.W. Passavant and J.A. Byers. 2003. DNA microsatellites of pronghorn (Antilocapra americana). Molecular Ecology Notes 3:10-11.

Cornuet, J.M. and G. Luikart. 1997. Description and power analysis of two tests for detecting recent population bottlenecks from allele frequency data. Genetics 144:2001-2014.

Di Rienzo, A., A.C. Peterson, J.C. Garza, A.M. Valdes, M. Slatkin and N. B. Freimer. 1994. Mutational processes of simple-sequence repeat loci in human populations. Proceedings of the National Academy of Sciences of the United States of America 91:3166-3170.

Ellegren, H. 2000. Microsatellite mutations in the germline: implications for evolutionary inference. Trends in Genetics 16:551-558.

Ellegren, H. 2004. Microsatellites: simple sequences with complex evolution. Nature Reviews Genetics 5:435-445.

Garza, J. C. and E.G. Williamson. 2001. Detection of reduction in population size using data from microsatellite loci. Molecular Ecology 10:305318.

Goodman, D. 1996. Viability analysis of the antelope population wintering near Gardiner, Montana. Unpublished report. U.S. National Park Service, Yellowstone National Park, WY. 
Hanski, I.A. and M.E. Gilpin. 1997. Metapopulation biology: ecology, genetics, and evolution. Academic Press, San Diego.

Keating, K. 2002. History of pronghorn population monitoring, research, and management in Yellowstone National Park. US Geological Survey - Northern Rocky Mountain Science Center, Bozeman, Montana.

Kimura, M. and J.F. Crow. 1964. The number of alleles that can be maintained in a finite population. Genetics 49:725-738.

Lee, T.E.J. 1994. Mitochondrial DNA and allozyme analysis of North American pronghorn populations. Journal of Wildlife Management 58:307-318.

Lou, Y. 1998. Genetic variation of pronghorn (Antilocapra americana) populations in North America. PhD. Texas A\&M University, College Station, Texas.

Luikart, G., F.W. Allendorf, J.M. Cornuet and W.B. Sherwin. 1997. Distortion of allele frequency distributions provides a test for recent population bottlenecks. Journal of Heredity 89:238-247.

Luikart, G. and J.M. Cornuet. 1998. Empirical evaluation of a test for identifying recently bottlenecked populations from allele frequency data. Conservation Biology 12:228237.

National Research Council. 2002. Ecological dynamics on Yellowstone's northern range. National Academy Press, Washington, D.C.

Ohta, T. and M. Kimura. 1973. The model of mutation appropriate to estimate the number of electrophoretically detectable alleles in a finite population. Genetics Research 22:201-204.

Reat, E. P., O.E. Rhodes Jr., J. R. Heffelfinger, and J. C. Devos Jr. 1999. Regional genetic differentiation in Arizona pronghorn. Proceedings of the 18th Biennial Pronghorn Antelope Workshop 18:25-31.

Rhodes Jr., O. E., R. N. Williams, J. R. Heffelfinger, L. K. Page, E. P. Reat and J. C. Devos Jr. 1999. Genetic variation in pronghorns from Arizona. Proceedings of the 18th Biennial Pronghorn Antelope Workshop 18:53-60.
Schneider, S., D. Roessli and L. Excoffier. 2000. Arlequin: A software for population genetics data analysis. Version 3.11. Genetics and Biometry Lab, Department of Anthropology, Geneva, Switzerland.

Scott, M.D. 1992. Buck-and-pole fence crossing by 4 ungulate species. Wildlife Society Bulletin

Scott, M.D. 2004. History of pronghorns translocated from Yellowstone National Park. Proceedings of the 21st Biennial Pronghorn Antelope Workshop 21:114-133.

Scott, M.D. and H. Geisser. 1996. Pronghorn migration and habitat use following the 1988 Yellowstone fires. Pages 123-132 In: Proceedings of the Second Biennial Conference on the Greater Yellowstone Ecosystem: ecological implications of fire in Greater Yellowstone. U.S. National Park Service, Fairfield, Washington.

Skinner, M.P. 1922. The prong-horn. Journal of Mammalogy 3:82-105.

Stephen, C.L., D.G. Whittaker, D. Gillis, L.L. Cox, and O.E. Rhodes. 2005a. Genetic consequences of reintroductions: an example from Oregon pronghorn antelope (Antilocapra americana). Journal of Wildlife Management 69:14631474.

Stephen, C.L., J.C. Devos Jr., T.E. Lee Jr., J.W. Bickham, J.R. Heffelfinger and O.E. Rhodes Jr. 2005b. Population genetic analysis of Sonoran pronghorn (Antilocapra americana sonoriensis). Journal of Mammalogy 86:782792.

Valiere, N. 2002. GIMLET: a computer program for analysing genetic individual identification data. Molecular Ecology Notes 2:377-379.

Waits, L.P., G. Luikart, and P. Taberlet. 2001. Estimating the probability of identity among genotypes in natural populations: cautions and guidelines. Molecular Ecology 10:249-256.

Wehausen, J.D., R.R. Ramey II and C.W. Epps. 2004. Experiments in DNA extraction and PCR amplification from bighorn sheep feces: the importance of DNA extraction method. Journal of Heredity 95:503-509. 
White, P.J., J.E. Bruggeman and R.A. Garrott. 2007a. Irruptive population dynamics in Yellowstone pronghorn. Ecological Applications 17:15981606.

White, P.J., T.L. Davis, K.K. Barnowe-Meyer, R.L. Crabtree and R.A. Garrott. 2007b. Partial migration and philopatry of Yellowstone pronghorn. Biological Conservation 135:502510.
Wilson, G.A. and B. Rannala. 2003. Bayesian inference of recent migration rates using multilocus genotypes. Genetics 163:1177-1191. 